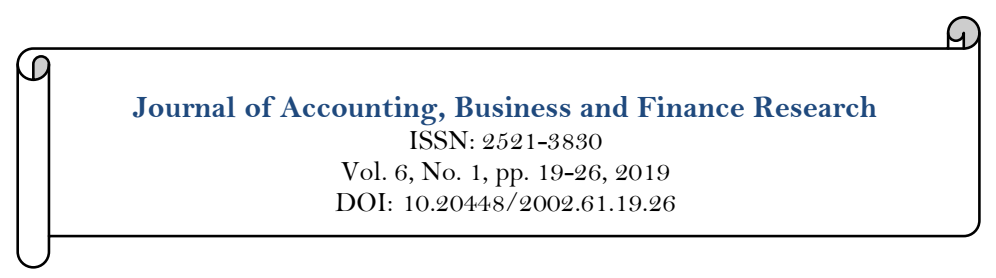

$\checkmark$ updates

\title{
Work-Life Balance and Performance of Female Medical Practitioners of Federal Government owned Medical Centres in Edo State, Nigeria
}

\author{
Akhator, P.A ${ }^{1}$ \\ Ohue Paul Itua ${ }^{2}$
}

'Department of Business Administration, Faculty of Management Sciences, Ambrose Alli University, Ekpoma, Edo State, Nigeria. -Department of Business Administration, Faculty of Management Sciences, Nnamdi Azikiwe University, Awka, Anambra State, Nigeria. Email:ohuepaulitua@yahoo.com

\begin{tabular}{|c|c|}
\hline Abstract & \\
\hline $\begin{array}{l}\text { The broad objective of this paper is to determine the effect of work-life balance } \\
\text { on performance of female medical practitioners of federal government owned } \\
\text { medical centres in Edo state. Specifically, this study seeks to ascertain the effect } \\
\text { of employee support on the commitment of married female medical } \\
\text { practitioners of university of Benin teaching hospital and Irrua specialist } \\
\text { teaching hospital. Survey research design was adopted for the study, a sample } \\
\text { size of two hundred and eighty (280) was used for the study, Krejcie and } \\
\text { Morgan (1970) sampling technique was used for the study, the data collection } \\
\text { tool employed by the researchers was the questionnaire, while the analysis of the } \\
\text { data was done using the linear regression analysis. The findings revealed that } \\
\text { employee support impacts the commitment of married female medical } \\
\text { practitioners of university of Benin teaching hospital and Irrua specialist } \\
\text { teaching hospital, Edo state since (F = 964.986; R2 = o.836; P <.O5). The } \\
\text { researchers therefore concluded that work-life balance impacts employee } \\
\text { performance of the institutions in focus. Based on the foregoing, the researchers } \\
\text { recommended the enactment of favourable work-life balance policies by the } \\
\text { institutions in focus and the approval of emergency leave for female (married) } \\
\text { medical practitioners of the institutions in focus because of their role in the } \\
\text { family. }\end{array}$ & $\begin{array}{l}\text { Keywords: } \\
\text { Work-life balance } \\
\text { Employee performance } \\
\text { Employee support } \\
\text { Employee commitment. } \\
\text { Licensed: } \\
\text { This work is licensed under a } \\
\text { Creative Commons Attribution } 4.0 \\
\text { License. } \\
\text { Publisher: } \\
\text { Scientific Publishing Institute }\end{array}$ \\
\hline
\end{tabular}

Funding: This study received no specific financial support.

Competing Interests: The authors declare that they have no competing interests.

\section{Introduction}

The concept 'work-life balance' (WLB) began to receive consideration in the field of management and other disciplines in 1970s. It is used to describe the balance between an individual's work and personal life. Presently, a vast majority of employees seem to be working longer and harder than ever before and as a consequence are finding it difficult to strike a balance between work and their personal life (Sturges \& Guest, 2004).

There is a complex relationship between work and personal life of individuals. In Nigeria today, this concept has gained widespread consideration as employees of Nigerian institutions find it difficult to strike a balance between work and personal life. Again, the burden on employees brought about by the failure of the management of medical centres in Africa (Nigeria inclusive) has necessitated this study (Hakanen, Arnold, \& Wilmar, 2006). This gives credence to the determination of the effect of work-life balance on performance of female medical practitioners of Federal government owned medical centres in Edo state, Nigeria. The study of female medical practitioners was borne out of the fact that the negative effect of the failure to strike a balance between work and personal life affects female employees the most. Clark (2000) defined Work-life balance as 
satisfaction and smooth functioning at work and home without any role conflict. Work-life balance can be defined as a measure of proper control as to how, when and where people work.

Proper work life balance can be achieved when an individual is able to fulfill all his/her needs in respect of family, work and society. Within the social and management sciences, there is much contemporary concern regarding work-life balance (Warren, 2004).With increasing demands and pressures of work-life, conflicts between work and personal roles seem to be increasing. Changed demographics of the workforce have been the primary force for the increased focus on family-work issues. Organizations where there is sound work-life balance practices and policies have a way of impacting the performance level of employees (Fleetwood, 2007). The nature of an organization's work-life balance practices and policies could impact employee absenteeism, employee productivity; customer experience; employee retention; firm overheads and employee commitment (Fleetwood, 2007).

The foregoing necessitated the study of the work-life balance of female medical practitioners of federal government owned medical centres (University of Benin teaching hospital and Irrua specialist teaching hospital) Edo state.

The researchers observed that the management of the institutions in focus fail to give female medical practitioners the required support when it comes to issues relating to child care, care for family member in need of care or emergency leave. This could directly impact the commitment level of these employees.

The broad objective of this study is to determine the effect of work-life balance on performance of female medical practitioners of federal government owned medical centres in Edo state.

Specifically, this study seeks to ascertain the effect of employee support on the commitment of married female medical practitioners of the institutions in focus.

\section{Review of Related Literature}

\subsection{Conceptual Review}

2.1.1. Work-life Balance

Work- life balance is a broad and complex phenomenon, lacking in a universal definition (Greenhaus, Collins, \& Shaw, 2003; Maxwell \& McDougall, 2004). Greenhaus et al. (2003) define work family balance as the "extent to which an individual is equally engaged in and equally satisfied with his or her work role and family role". That is, work life balance includes satisfaction and good functionality at work, as well as at home with a minimum of role conflicts (Clark, 2000). Greenhaus et al. (2003) further suggest that work life balance is defined by three key, and interconnected, components: firstly, "time balance" which refers to equal time being given to both work and non-work roles; secondly, "involvement balance" which refers to equal levels of psychological involvement in both work and family roles; and finally, "satisfaction balance" which refers to equal levels of satisfaction in both work and family roles. Therefore, in order to achieve a work life balance these components should be considered Greenhaus et al. (2003).

When an imbalance or interference occurs between work and family (or non work) roles for an individual this can result in conflict. The most widely cited definition of work family conflict states that it is "a form of inter-role conflict in which the role pressures from the work and family domains are mutually incompatible in some respect. That is, participation in the work (family) role is made more difficult by virtue of participation in the family (work) role" Greenhaus et al. (2003). According to this definition, work family conflict can occur in two directions: family can interfere with work (family to work conflict) or work can interfere with family (work to family conflict). Empirical research on predicators and outcomes support the idea that family to work and work to family conflict are two distinct constructions (Bellavia \& Frone, 2005).

According to Evans (2002) four types of work-life balance policies can be used in an organization: firstly, employee support; secondly, flexible working arrangements; thirdly, support of child care or care for family members in need of care; and, finally, information management (informing employees of the benefits accrued to them). The employee support aspect of work life balance policies will be used for this study.

\subsection{Employee Support}

A gap of employment can be due to necessities like maternity, child care, or care for family member in need of care or emergency leave (e.g., to deal with a sick child, or when there has been a problem with child care or elder care). Support can be given by job-protected maternity leave, parental leave for women, paid or unpaid special leave, time to be made up later or reduction in working hours (Evans, 2002).

\subsection{Employee Performance}

Kotler and Armstrong (2002) assert that employee performance is measured in terms of the quality of output (goods and services) produced by the employee. Employee performance is normally looked at in terms of outcomes. However, it can also be looked at in terms of behavior (Armstrong, 2001). Wright and Geroy (2001) opine that employee performance is a function of organizational performance. Therefore, in order for an organization to achieve a high performance level, employee have to be motivated so as to spur their performance. Kinicki and Kreitner (2007) assert that employee performance is higher in happy and satisfied workers. Therefore, management should strive to ensure that they have a motivated workforce in other to 
attain firm targets. Employee performance can also be seen as the job related activities of an employee and how well they are executed.

Kinicki and Kreitner (2007) opine that some employee key performance indicators are: Turnover rate, time required to complete task, product quality, return on training investment, revenue per employee, 360 degree feedback score, employee core competency profile, employee engagement level, organizational citizenship behavior, human capital value added, job satisfaction, employee commitment and employee innovation.

\subsection{Employee Commitment}

Employee commitment continues to be one of the most popularly researched subjects in the field of management (Chen \& Francesco, 2003). Chen and Aryee (2007) affirmed that commitment of employees is an important instrument for improving the performance of the organizations. Adekola (2012) defined commitment as being a positive evaluation of the organization and the organizations goals. According to Goutan (2004) employee commitment could be defined as a bond between an individual (the employee) and the organization (the employer). The level of employee commitment could be impacted by their involvement in the goal setting process of an organization. Miller and Lee (2001) identified three types of commitment; affective commitment, continuance commitment, and normative commitment.

\section{Theoretical Framework}

This study is anchored on Resource Based Theory propounded by Grant (1996). The resource-based theory comprises a rising and dominant area of the strategy literature which addresses the question of an organization's identity and it is principally concerned with the source, nature and utilization of strategic capabilities. The basis of the resource-based theory is that firms will be dominant in the industry they belong when they have a motivated workforce. (Teece, Pisano, \& Shuen, 1991). A motivated workforce can be ensured by the nature of an organization's work-life balance policies.

\section{Empirical Review}

Fapohunda (2014) investigated the effect of work-life balance on productivity. Two hundred respondents were randomly selected from the banking industry in Nigeria. Questionnaire was the data collection tool employed, chi-square statistical tool was used to analyse the collected data. The findings revealed a positive relationship between work-life balance policies and employee commitment.

Ojo (2012) examined the effect of work-life balance policies and practices on employee performance in the Nigerian banking sector. Six hundred respondents were used for the study, questionnaire was the data collection tool employed, spearman's correlation was used to analyse the collected data. The findings revealed that work-life balance policies impacts employee performance.

Lubna (2013) examined the effectiveness of work-life balance in the banking sector in Pakistan. Survey research design was used for the study, questionnaire was the data collection employed, chi-square statistical tool was used to analyse the collected data. The findings revealed that work-life balance impacts employee performance.

Mohanty and Mohanty (2014) examined employee perception on work-life balance in Odisha, India. One hundred professionals randomly selected from different hotels in Bhubaneswar with the help of a questionnaire was used for the study. Regression analysis was used to test the formulated hypothesis. Results showed that work-life balance impacts employee performance of the organizations in focus.

Irfan and Azimi (2015) examined work-life balance among university and school teachers in Aligarh. Descriptive research design was used for the study, one hundred and twelve copies of the questionnaire was used to analyse the collected data, t-test statistics was used to test the hypothesis. The findings revealed that work-life imbalance impacts the efficiency of teachers.

\subsection{Gap in Knowledge}

None of the empirically reviewed examined work-life balance as it relates to performance of female medical practitioners of federal government owned medical centres in Edo state, Nigeria. This is the gap in knowledge that this study intends to fill.

\section{Methodology}

5.1. Research Design

The research design adopted for this study was the survey research design. It was used because of the nature of the study. Survey research design enables the researcher to observe what happens to the sample subjects without manipulating them. Only married female medical practitioners were used for this study. 


\subsection{Population of Study}

Table-1. Population of Female Medical Practitioners in the Institutions of Study

\begin{tabular}{l|c}
\hline Institution & Female Medical Practitioners \\
\hline University of Benin Teaching Hospital. & 878 \\
\hline Irrua Specialist Teaching Hospital. & 692 \\
\hline Total & $\mathbf{1 , 5 7 0}$ \\
\hline Source: Personnel Department of the Institutions of Study (2018).
\end{tabular}

The Table 1 above shows that University of Benin teaching hospital has eight hundred and seventy eight female medical practitioners, while Irrua specialist teaching hospital has six hundred and ninety two.

\subsection{Sample Size and Sampling Technique} below:

The Krejcie and Morgan (1970) sampling technique was used for this study. The formular is denoted

$$
S=\frac{x^{2} N P(1-P)}{d^{2}(N-1)+x^{2} P(1-P)}
$$

Where $\mathrm{S}=$ Sample Size

$\mathrm{X}^{2}=$ Table value of chi-square for 1 degree of freedom 0.05 confidence level (3.84)

$\mathrm{N}=$ population Size $(1,570)$

$\mathrm{P}=$ Population proportion $(0.5)$

$\mathrm{d}=$ Degree of accuracy $(0.05)$

$\mathrm{S}=3.48(1,570)(0.5)(1-0.5) / 0.05^{2}(1,570-1)+3.84(0.5)(1-0.5)$

$\mathrm{S}=(2731.8)(0.5) / 3.92+0.96$

$\mathrm{S}=1,365.9 / 4.88$

$\mathrm{S}=279.8=280$

Based on the above, 280 copies of the questionnaire were randomly distributed to married female medical practitioners in the institutions of study.

\subsection{Instrument of Data Collection}

The data collection tool employed by the researcher was the questionnaire. It was designed on a five point Likert Scale. Strongly Agreed (SD), Agreed (A), Undecided (U), Strongly Disagreed (SD) and Disagreed (D).

The Bowley (1926) allocation formula was used to determine the copies of the questionnaire to be distributed to each institution. The formula is denoted thus:

$\mathrm{Nh}=\mathrm{n}(\mathrm{nh}) / \mathrm{N}$

Where $\mathrm{Nh}=$ Number of units to be distributed to each group.

$\mathrm{nh}=$ Number of respondents in each group.

$\mathrm{n}=$ Total Sample Size.

$\mathrm{N}=$ Total Population Size.

University of Benin Teaching Hospital (UBTH):

$\mathrm{Nh}=280(878) / 1,570=245,840 / 1,570$

$=156.6=157$.

One hundred and fifty seven copies of the questionnaire were distributed to married female medical practitioners of University of Benin Teaching Hospital (UBTH).

Irrua Specialist Teaching Hospital (ISTH):

$\mathrm{Nh}=280(692) / 1,570=193,760 / 1,570$

$=123.4=123$.

One hundred and twenty three copies of the questionnaire were distributed to married female medical practitioners of Irrua Specialist Teaching Hospital (ISTH).

\subsection{Validity of the Instrument}

Validity is the extent to which an instrument measures what it intends to measure. The content and face validity test was used by the researcher.

\subsection{Reliability of the Instrument}

This is a measure of the consistency of a particular instrument employed by a researcher. The Cronbach's Alpha reliability test was used for the study. Suwannoppharat and Kaewsa (2015) asserts that a reliability coefficient of 0.696 and above is acceptable. Therefore, a benchmark of 0.696 was used for the study. 
Table-2. Scale: Reliability Statistics for Work-Life Balance.

\begin{tabular}{l|l}
\hline Cronbach's Alpha & N of Items \\
\hline .742 & 5 \\
\hline Source: Field survey, 2018.
\end{tabular}

Since the Cronbach's Alpha score Table 2 of the reliability statistics for work-life balance $0.74>0.696$, it shows that the instrument is reliable.

\begin{tabular}{l|l}
\multicolumn{2}{c}{ Table-3. Scale: Reliability Statistics for Employee Performance. } \\
\hline Cronbach's Alpha & N of Items \\
\hline .780 & 5 \\
Source: Field survey, 2018.
\end{tabular}

Since the Cronbach's Alpha score Table 3 of the reliability statistics for employee performance $0.78>0.696$, it shows that the instrument is reliable. The results of the reliability test were indications of the internal consistency of the instrument.

\section{Method of Data Analysis}

Linear regression analysis was used to analyse the collected data. This was done with the aid of Statistical Package for Social Sciences (SPSS) version 20.

\subsection{Data Presentation and Analysis}

Table-4. Table of Returned and Unreturned Questionnaire.

\begin{tabular}{l|l|l}
\hline \multicolumn{2}{l}{ Analysis of Returned and Unreturned Questionnaire } \\
\hline Returned Questionnaire (Valid) & 202 & 72.14 \\
\hline Returned Questionnaire (Invalid) & 18 & 06.43 \\
\hline Unreturned Questionnaire & 60 & 21.43 \\
\hline Total Questionnaire Administered & 280 & 100 \\
\hline \multicolumn{3}{l}{ Source: Field Survey, (2018). }
\end{tabular}

Based on the Table 4, two hundred and two copies of the questionnaire were used for the study. What is the effect of employee support on commitment of married female medical practitioners of university of Benin teaching hospital and Irrua specialist teaching hospital?

\begin{tabular}{l|l|l|l|l|l}
\multicolumn{7}{c}{ Table-5. Descriptive Statistics of the Analysed Data (Employee support). } \\
\hline & $\mathbf{N}$ & Minimum & Maximum & Mean & Std. Deviation \\
\hline Q1 & 202 & 1.00 & 5.00 & 3.1056 & 1.41620 \\
\hline Q2 $^{2}$ & 202 & 1.00 & 5.00 & 3.0112 & 1.41816 \\
\hline Q3 & 202 & 1.00 & 5.00 & 3.0225 & 1.67384 \\
\hline Q4 & 202 & 1.00 & 5.00 & 3.1056 & 1.51620 \\
\hline Q5 & 202 & 1.00 & 5.00 & 3.1000 & 1.42218 \\
\hline Valid N (listwise) & 202 & & & & \\
\hline Source: Field survey, 2018. &
\end{tabular}

A bench-mark of 2.5 was used for the study. Since the mean values of all the questions for employee support are above 2.5 , it shows that all the questions were acceptable for the study Table 5 . Hence, they were all used for the study. A bench-mark of 2.5 was used for the study. Since the mean values of all the questions for employee commitment are above 2.5, it shows that all the questions were acceptable for the study Table 6. Hence, they were all used for the study.

Table-6. Descriptive Statistics of the Analysed Data (Employee commitment).

\begin{tabular}{|c|c|c|c|c|c|}
\hline \multicolumn{6}{|c|}{ Descriptive Statistics } \\
\hline & $\mathbf{N}$ & Minimum & Maximum & Mean & Std. Deviation \\
\hline Q1 & 202 & 1.00 & 5.00 & 2.8831 & 1.41611 \\
\hline $\mathrm{Q}^{2}$ & 202 & 1.00 & 5.00 & 2.9944 & 1.41220 \\
\hline Q3 & 202 & 1.00 & 5.00 & 3.0112 & \begin{tabular}{|l|}
1.66719 \\
\end{tabular} \\
\hline $\mathrm{Q}^{4}$ & 202 & 1.00 & 5.00 & 3.0000 & 1.42218 \\
\hline Q5 & 202 & 1.00 & 5.00 & 2.7888 & 1.41417 \\
\hline Valid N (listwise) & 202 & & & & \\
\hline
\end{tabular}


6.2. Test of Hypothesis

Ho: Employee support does not impact the commitment of married female medical practitioners of university of Benin teaching hospital and Irrua specialist teaching hospital.

Table-7. Model Summary of Regression Output

\begin{tabular}{l} 
Model \\
\cline { 5 - 9 }
\end{tabular}

Table-8. ANOVA Result from Regression Output.

\begin{tabular}{l|l|l|l|l|l|l}
\hline \multicolumn{2}{l|}{ Model } & Sum of Squares & Df & Mean Square & F & Sig. \\
\hline \multirow{3}{*}{1} & Regression & 301.544 & 1 & 301.544 & 964.986 & $.000^{\mathrm{b}}$ \\
\cline { 2 - 8 } & Residual & 54.433 & 176 & .309 & & \\
\cline { 2 - 7 } & Total & 355.978 & 177 & & & \\
\multicolumn{2}{l}{ a. Dependent Variable: Employee Commitment. }
\end{tabular}

b. Predictors: (Consta

Table-9. Coefficients from Regression Output.

\begin{tabular}{|c|c|c|c|c|c|c|c|c|}
\hline \multirow{2}{*}{\multicolumn{2}{|c|}{ Model }} & \multicolumn{2}{|c|}{$\begin{array}{l}\text { Unstandardized } \\
\text { Coefficients }\end{array}$} & \multirow{2}{*}{$\begin{array}{l}\text { Standardized } \\
\text { Coefficients } \\
\text { Beta }\end{array}$} & \multirow[t]{2}{*}{$\mathbf{t}$} & \multirow[t]{2}{*}{ Sig. } & \multicolumn{2}{|c|}{$\begin{array}{l}95.0 \% \text { Confidence } \\
\text { Interval for } \mathrm{B}\end{array}$} \\
\hline & & B & Std. Error & & & & $\begin{array}{l}\text { Lower } \\
\text { Bound }\end{array}$ & $\begin{array}{l}\text { Upper } \\
\text { Bound } \\
\end{array}$ \\
\hline & $\begin{array}{l}\text { (Cons } \\
\operatorname{tant})\end{array}$ & .291 & .097 & & 3.012 & .003 & .100 & .481 \\
\hline 1 & $\begin{array}{l}\text { Empl } \\
\text { oyee } \\
\text { Supp } \\
\text { ort }\end{array}$ & .848 & .027 & .930 & 31.225 & .000 & .794 & .902 \\
\hline
\end{tabular}

The result obtained from the regression analysis Table 7, 8 and 9 shows that employee support has significant effect on employee commitment $(\beta=0.930, \mathrm{t}=31.225, \mathrm{P}<.05)$. Also, employee support is a predictor of employee commitment $(\mathrm{F}=964.986 ; \mathrm{R} 2=0.836 ; \mathrm{P}<.05)$. The predictor variable single handedly explained $83.6 \%$ of the variance in employee commitment, while the remaining $16.4 \%$ could be due to the effect of extraneous variables. The durbin-watson value of 1.847 shows that there is no first serial order correlation. This makes the result respectable.

\section{Discussion of Findings}

Results from the test of the hypothesis shows that employee support impacts the commitment of married female medical practitioners of university of Benin teaching hospital and Irrua specialist teaching hospital. This corroborates the work of Fapohunda (2014). He investigated the effect of work-life balance on productivity. The findings of the study revealed a positive relationship between work-life balance policies and employee commitment. The work of Ojo (2012) on the effect of work-life balance policies and practices on employee performance in the Nigerian banking sector is also in line with the findings obtained from the test of the formulated hypothesis. The findings revealed that work-life balance policies impacts employee performance. Lubna (2013) examined the effectiveness of work-life balance in the banking sector in Pakistan. The study is also in line with the result of this study. The findings revealed that work-life balance impacts employee performance.

\section{Summary of Findings}

Findings from the test of the formulated hypothesis shows that employee support impacts the commitment of female medical practitioners of university of Benin teaching hospital and Irrua specialist teaching hospital since $(\mathrm{F}=964.986 ; \mathrm{R} 2=0.836 ; \mathrm{P}<.05)$.

\section{Conclusion}

Based on the findings, the researchers concludes that work-life balance impacts the performance of female medical practitioners of university of Benin teaching hospital and Irrua specialist teaching hospital. The study revealed that when the female medical practitioners of the institutions in focus get the desired support from the management of their organization, it could impact their commitment level. 


\section{Recommendations}

The researchers made the following recommendations based on the findings of the study:

1. Enactment of favourable work-life balance policies by the institutions in focus.

2. Approval of emergency leave for female (married) medical practitioners of the institutions in focus because of their role in the family.

\section{References}

Adekola, B. (2012). The impact of organizational commitment on job satisfaction: A study of employee at Nigerian Universities. International Journal of Human Resources Studies, 2(2), 20-29.

Armstrong, M. (2001). A handbook of human resources management practices. London: Kogan Page Limited.

Bellavia, G. M., \& Frone, M. R. (2005). Work-family conflict. In: Barling, J., Kelloway, E.K., Frone, M.R (Eds), Handbook of Work Stress. London: Sage Publications.

Bowley, A. L. (1926). Measurement of the precision attained in sampling. Bulletin of the International Institute of Statistics, $22(1), 1-62$

Chen, Z. X., \& Aryee, S. (2007). Delegation and employee work outcomes: An examination of the cultural context of mediating processes in China. Academy of Management Journal, 50(1), 226-236.

Chen, Z. X., \& Francesco, A. M. (2003). The relationship between the three components of commitment and employee performance in China. Journal of Vocational Behavior, 62, 490-510.

Clark, S. C. (2000). Work/family border theory: A new theory of work/family balance. Human Relations, 53, 747-770.

Evans, J. (2002). Work/family reconciliation, gender wage equity and occupational segregation: The role of firms and public policy. Canadian Public Policy, 28, 187-216.

Fapohunda, T. M. (2014). An exploration of the effects of work-life balance on productivity. Journal of Human Resources Management and Labour Studies, 2(2), 71-89.

Fleetwood, S. (2007). Why work-life balance now? International Journal of Human Resource Management, 18(3), 387-400

Goutan, S. (2004). Determinant of career satisfaction among federal employees. Paper presented at the Paper Presented at the Seminar on Public Policy. Georgia Institute of Technology, Georgia, USA.

Grant, R. M. (1996). Toward a knowledge-based theory of the firm. Strategic Management Journal, 14(17), 109-122.

Greenhaus, H. J., Collins, M. K., \& Shaw, D. J. (2003). The relation between work-family balance and quality of life. Journal of Vocational Behaviour, 61(63), 510-531.

Hakanen, J. J., Arnold, B. B., \& Wilmar, B. S. (2006). Burnout and work engagement among teachers. Journal of School Psychology, 40(43), 495-513.

Irfan, A., \& Azimi, T. (2015). Work-life balance among teachers: An empirical study. Journal of Business and Management, $17(2), 1-11$.

Kinicki, A., \& Kreitner, R. (2007). Organizational behavior. New York: McGraw-Hill.

Kotler, P., \& Armstrong, G. (2002). Marketing: An introduction (6th ed.). London: Prentice-Hall.

Krejcie, R. V., \& Morgan, D. W. (1970). Determination of sample size for research activities. Educational and Psychological Measurement, 30(21), 607-610.

Lubna, R. V. (2013). An empirical study of the effectiveness of work-life balance in the banking industry. Life Science Journal, 10(4), 3075-3081.

Maxwell, A. G., \& McDougall, M. (2004). Work-life balance: Exploring the connections between levels of influence in the UK public sector. Public Management Review, 6(3), 377-393.

Miller, D., \& Lee, J. (2001). The people make the process: Commitment to employees, decision-making and performance. Journal of Management, 23(27), 163-189.

Mohanty, K., \& Mohanty, S. (2014). An empirical study of employee perception of work-life balance in the hotel industry with special reference to Odisha. Journal of Tourism and Hospitality Management, 2(2), 65-81.

Ojo, S. (2012). Work-life balance policies and practices: Manager and employee experience in the Nigerian banking sector. Brunel Business School-Doctoral Symposium 27th and 28th March.

Sturges, J., \& Guest, D. (2004). Working to live or living to work? Work-life balance early in the career. Human Resource Management Journal, 14(12), 20-28.

Suwannoppharat, K., \& Kaewsa, A. (2015). Utilization of content. Theme based instruction: An overhaul of English language learning for non-native English learners. International Journal of English Language Education, 1(3), 115126.

Teece, D. J., Pisano, G., \& Shuen, A. (1991). Dynamic capabilities and strategic management. Strategic Management Journal, $18(7), 509-533$.

Warren, T. (2004). Working part-time: Achieving a successful work-life balance? The British Journal of Sociology, 1(1), 1829.

Wright, P., \& Geroy, D. G. (2001). Changing the mindset: The training myth and the need for word-class performance. International Journal of Human Resource Management, 12(4), 586-600. 


\section{Appendix 1}

Questionnaire Items on Work-life Balance and Employee Performance

Options: Strongly Agree $=$ SA, Agree $=$ A, Undecided $=$ UD, Strongly Disagree $=$ SD, Disagree $=$ D. Please tick ( ) as it represents your view

\begin{tabular}{|c|c|c|c|c|c|c|}
\hline & $\begin{array}{l}\begin{array}{l}\text { Questionnaire Item for Independent Variable(Work-life } \\
\text { balance) }\end{array} \\
\end{array}$ & & & & & \\
\hline No & Employee support & $\begin{array}{l}\text { SA } \\
5\end{array}$ & $\begin{array}{l}\mathbf{A} \\
4\end{array}$ & $\begin{array}{l}\text { UD } \\
3\end{array}$ & $\begin{array}{l}\text { SD } \\
2\end{array}$ & $\begin{array}{l}\mathbf{D} \\
1\end{array}$ \\
\hline 1 & $\begin{array}{l}\text { You will be pleased if there is a standard day care in your } \\
\text { organization. }\end{array}$ & & & & & \\
\hline 2 & $\begin{array}{l}\text { There are occasions where emergencies in the home front would } \\
\text { warrant you to stay out of work for awhile. }\end{array}$ & & & & & \\
\hline 3 & $\begin{array}{l}\text { You would like the work-life balance policies in your institution } \\
\text { to be improved upon. }\end{array}$ & & & & & \\
\hline 4 & $\begin{array}{l}\text { There is the existence of work-life balance policies in your } \\
\text { institution. }\end{array}$ & & & & & \\
\hline \multirow[t]{3}{*}{5} & $\begin{array}{l}\text { Your job has made it impossible for you to attend to some } \\
\text { pressing family needs. }\end{array}$ & & & & & \\
\hline & Dependent Variable (Employee Performance) & & & & & \\
\hline & Employee commitment & & & & & \\
\hline 1 & You always attend to the needs of patients. & & & & & \\
\hline 2 & You are always at your duty post at the right time. & & & & & \\
\hline 3 & You always empathize with patients. & & & & & \\
\hline 4 & $\begin{array}{l}\text { You strive towards maintaining a cordial relationship with } \\
\text { patients. }\end{array}$ & & & & & \\
\hline 5 & You would like to retire in your institution. & & & & & \\
\hline
\end{tabular}

